\title{
Local differences in habitat selection by Great Bustards Otis tarda in changing agricultural landscapes: implications for farmland bird conservation
}

\author{
JUAN LÓPEZ-JAMAR, FABIÁN CASAS, MARIO DÍAZ and \\ MANUEL B. MORALES
}

\begin{abstract}
Summary
Local changes in land use can influence patterns of habitat selection by farmland birds, thus biasing predictions of population responses to land use changes based on wildlife-habitat or niche modelling. This study, based in arable farmland in south-central Spain, determined whether habitat selection (use of agricultural habitats and the distance to roads, tracks and buildings) by Great Bustards Otis tarda varied between two nearby areas with differing land uses. The western sector has experienced a process of land abandonment and infrastructure development linked to an airport project that started in 1998 and finished in 2009, while the eastern sector maintains extensive dry farmland systems. Great Bustards avoided ploughed fields and selected short- and long-term fallows. Selection of fallows was more intensive in the sector suffering recent land-use changes, where these substrates were more abundant. Great Bustards were distributed further from roads, paths and buildings than would be expected if individual birds selected habitats at random. Avoidance of infrastructure was strongest in the area suffering recent land-use changes. Local patterns of habitat selection seemed to change in relation to agricultural abandonment and infrastructure development. Consequently, conservation measures based on knowledge of broad patterns of habitat use and selection such as agri-environmental schemes may fail to ensure steppe bird conservation locally if such local effects are overlooked. Specifically, schemes should include landscape-scale restrictions on the development and use of infrastructure (roads, tracks and buildings). Analyses of the patterns and causes of local and regional changes in habitat selection are essential to conserve populations of endangered farmland birds.
\end{abstract}

\section{Resumen}

Los cambios locales en los usos del suelo pueden influir en los patrones de selección de hábitat de las aves esteparias, sesgando las predicciones de sus respuestas a los cambios de los usos del suelo basadas en modelos especies-hábitat. En este estudio, realizado en áreas agrícolas del centro-sur de España, estudiamos si la selección de hábitat (uso de sustratos agrarios y distancias a carreteras, caminos y edificaciones) de la Avutarda Común Otis tarda cambia entre dos zonas contiguas que difieren en sus cambios recientes en los usos del suelo. El sector oeste de nuestra área de estudio ha sufrido un proceso de abandono de cultivos y construcción de diversas infraestructuras vinculadas al proyecto de construcción de un aeropuerto, iniciado en 1998 y finalizado en 2009, mientras que el sector este ha mantenido sus usos agrícolas extensivos. Las Avutardas evitaron los campos labrados y seleccionaron los barbechos, tanto recientes como de larga duración. Lo barbechos fueron más seleccionados en el sector que sufrió cambios en los usos del suelo, donde 
estos sustratos fueron más abundantes. Las Avutardas se alejaron de carreteras, caminos y edificaciones más de lo esperado al azar, y significativamente más en el área más alterada. Los patrones locales de selección de hábitat parecen cambiar en relación al abandono de los cultivos y la presencia de distintos tipos de infraestructuras. Consecuentemente, las medidas de conservación basadas en el conocimiento de patrones generales de uso y selección del hábitat, tales como los programas agroambientales, podrían no ser eficaces para la conservación de las aves esteparias si estos cambios locales no se tienen en cuenta. El análisis de los patrones y causas de la selección de hábitat tanto a nivel local como regional es por tanto esencial para preservar las poblaciones de aves esteparias amenazadas.

\section{Introduction}

Farmland and steppe birds are threatened all over Europe by the rapid rate of change in the agricultural landscapes on which they depend (Chamberlain et al. 2000, Donald et al. 2001, 2007, Bota et al. 2005). Agricultural intensification is often claimed to be the main cause of population declines in farmland birds (Donald et al. 2001, 2007, Bota et al. 2005), although other human threats such as hunting or, more recently, increased mortality, disturbance and habitat fragmentation due to infrastructure development also play a role for several species or populations (Onrubia and Andrés 2005). The drive to increase food production has led to the widespread adoption of intensive agricultural practices. These range from increased fertiliser and pesticide inputs, increased field sizes, the loss of mixed farming, and land abandonment or land use changes in marginal areas (Atkinson and Robinson 2002; Benton et al. 2003; Bota et al. 2005, Concepción et al. 2008, Nikolov 2010).

Species-habitat models are most commonly used to determine the likely effects of changes in farm practices on farmland birds, and the results are used to predict future impacts and formulate solutions. Species-habitat models have been used, for instance, to map suitable habitats for agricultural steppe birds in Spain (Suárez-Seoane et al. 2002), to evaluate local and regional impacts of agricultural intensification (Díaz et al. 2001, Brotons et al. 2004), and to predict the effectiveness of agri-environmental schemes (Llusía and Oñate 2005, Whittingham et al. 2007).

Species-habitat models are excellent syntheses of current knowledge on the habitat requirements of the species involved. However, they should be used with caution in forecasting changes in distribution and abundance in the face of expected (or designed) changes in land use (Osborne 2005, Whittingham et al. 2007). Equilibrium distributions between organisms and resources, and between resources and habitat traits, are to be assumed during model building, a condition rarely met in disturbed systems (Morrison et al. 1998, Schlaepfer et al. 2002). Furthermore, using statistical models to predict future distributions often requires the modelled relationships between birds and habitats not to vary in space and time (Osborne 2005, Whittingham et al. 2007), a requirement that is rarely or never met in fast-changing agricultural systems (Tellería et al. 1994, Benton et al. 2003). Habitat use and selection may change quite suddenly in response to levels of human disturbance (Fox and Madsen 1997, Bautista et al. 2004, Webb and Blumstein 2005, Casas et al. 2009), and the most suitable habitats for survival and reproduction may remain unoccupied or under-utilised locally, depending on the nearby presence of alternative habitats with lower disturbance levels (Gill et al. 2001).

The Great Bustard Otis tarda is a typical agricultural steppe bird in Spain (Palacín et al. 2003, 2004). Research on this species has been focused on population monitoring and intensive studies on its biology during the last few decades (reviewed in Morales and Martín 2002, Palacín et al. 2003, 2004, Alonso et al. 2005, Morales et al. 2006, Palacín and Alonso 2008). The size of the Spanish population has currently stabilised around $27,500-30,000$ birds (c.60\% of the global population) after strong declines until the 1980s, apparently due to overhunting (Alonso et al. 2005, Palacín and Alonso 2008). Its range has however decreased due to local extinctions of marginal populations caused by habitat loss or degradation, and low recolonisation rates (Palacín et al. 2004). Slow population and range recovery, as well as several local extinctions, are 
attributed to the effects of agricultural intensification on habitat quality, as well as to strong site fidelity and conspecific attraction to already occupied sites (Alonso et al. 2004).

Habitat selection patterns by Great Bustards vary seasonally (e.g. Alonso and Alonso 1990, Hidalgo and Carranza 1990, Palacín et al. 1996), spatially (Morales et al. 2006) and among regions (Morales et al. 2006). Short- and long-term fallows, leguminous crops (Lucerne Medicago sativa, Common Vetch Vicia sativa) and growing cereal fields are usually selected to varying degrees depending on season and local availability, whereas ploughed fields and uncultivated habitats are consistently avoided year-round. Human artefacts such as buildings, roads, tracks and power lines are also consistently avoided (Alonso and Alonso 1990, Hidalgo and Carranza 1990, Lane et al. 2001).

Habitat suitability for Great Bustards in the Iberian Peninsula is determined by the additive effects of low altitude, flat topography, low-intensity cereal cultivation, and low levels of human disturbance (Suárez-Seoane et al. 2002). Nevertheless, to our knowledge, no study has examined whether these factors could interact in fast-changing agricultural landscapes. Local-scale changes in land use and levels of human disturbance could produce changes in the pattern of habitat selection by farmland birds, potentially biasing predictions of population responses to land use changes based on large-scale species-habitat models (see above and Osborne 2005). In this paper we took advantage of the development of a large infrastructure project (an airport) close to one of the key conservation areas for Great Bustards and other steppe birds identified by SuárezSeoane et al. (2002), the Campo de Calatrava (Ciudad Real, south-central Spain). We analysed the seasonal patterns of habitat selection of Great Bustards close to the area affected by the airport project compared to patterns in a nearby control site. We compared the use of agricultural habitats with its availability, as well as the distribution of birds according to distance from manmade infrastructures. If human disturbance interacts with patterns of habitat use, we expected to find differences in habitat selection between the two contiguous areas, as well as greater sensitivity to infrastructure closer to the developed area.

\section{Materials and methods}

\section{Study area}

The study area extends over $75 \mathrm{~km}^{2}$ and is located in Campo de Calatrava (Central Spain, $38^{\circ} 80$ N, $3^{\circ} 806 \mathrm{~W}, 610 \mathrm{~m}$ a.s.l.), within the municipal boundaries of Ciudad Real, Miguelturra, Pozuelo de Calatrava, Ballesteros de Calatrava and Villar del Pozo (Figure 1; more details in López-Jamar et al. 2004). It is an undulating farmland area dominated by a mosaic of crops, mainly dry cereals with interspersed patches of olive groves, vineyards and annual legumes. The area holds important steppe bird populations and is included within the Special Protection Area (SPA) "Área esteparia del Campo de Calatrava" (Suárez-Seoane et al. 2002; Figure 1) one of the hotspot areas for Spanish steppe birds identified by Traba et al. (2007).

The study area was divided into two sectors by a north-south road (Figure 1), each including a Great Bustard lek (Suárez et al. 2000; López-Jamar et al. 2004). The north-east sector (Miguelturra) extends over c.2,70o ha and the south-west sector (Ballesteros) over c.2,200 ha. Ciudad Real airport was developed close to the south-western corner of the Ballesteros sector (Figure 1). The airport project started in 1998 and finished in 2009. The original project was not approved by the Spanish authorities as it occupied part $(8.2 \%)$ of the Campo de Calatrava SPA (BOE 2001). A modified project located mostly outside the SPA was resubmitted and approved in 2002 (Figure 1; BOE 2002). Development work started in 2002, but had to be suspended in 2004, when $46 \%$ of the project had already been developed, due to a mandatory requirement of the European Commission (BOE 2006). After solving the queries raised by means of a new Environmental Impact Assessment of the airport and a full list of compensatory measures for the impacts on birds and other environmental aspects (e.g. noise; BOE 2006), the project was finally approved in 2008 (BOE 2008) and the airport started working in 2009 (BOE 2009). The development of the airport project produced obvious increases in the presence of people and vehicles in and around the developed area (pers. obs.). 


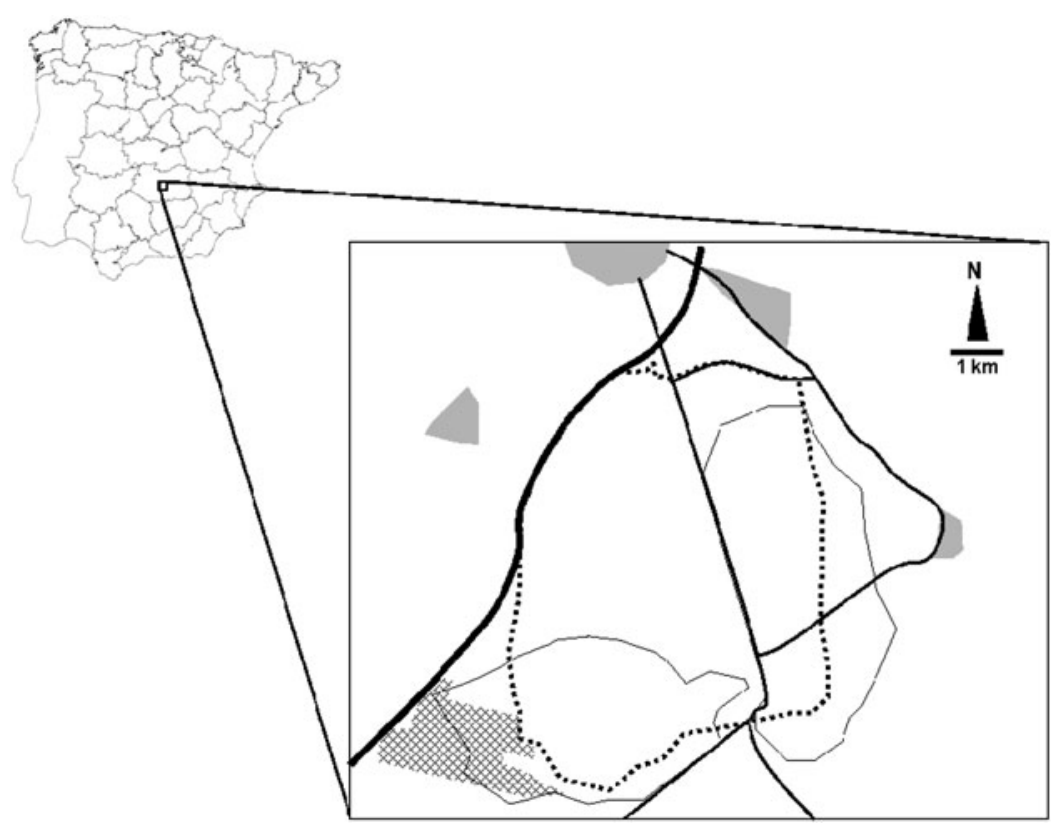

Figure 1. Map of the study area, showing the main cities and villages (light grey) and the area currently occupied by Ciudad Real Airport (hatched; source: Google Earth; www.earth.google. com). Thick continuous line: high-speed railway; continuous line: main roads; thin continuous line: study sectors (western: Ballesteros; eastern: Miguelturra); thick dotted line: limits of the SPA 157 'Campo de Calatrava' (6,500 ha; BOE 2006). The original airport project was larger, located $2 \mathrm{~km}$ north-east of the current one, and occupied 530 ha of the SPA (8.2\%; BOE 2001).

\section{Data collection}

Field work was carried out from September 2002 to June 2003. No data could be collected in November 2002 due to harsh weather. Great Bustards were located along permanent transects covering the whole study area; these were established in each study sector over the network of tracks ( $95 \%$ of transects) and roads in order to detect all birds present in them (Alonso and Alonso 1990, López-Jamar et al. 2004). The two transects were surveyed simultaneously once per month by two teams using four-wheel drive vehicles. Teams comprised at least two observers who drove at low speed $\left(20 \mathrm{~km} \mathrm{~h}^{-1}\right)$ and stopped regularly to look for, identify and count birds using binoculars (8x40) and telescopes (20-6ox). In order to avoid double-counts, both teams were in permanent contact by phone to control whether any birds flew away towards the other sector. Birds in flight were followed until landing. The availability of tracks within the study area allowed us to be confident that we correctly surveyed all the study area and detected all flocks and the most isolated individuals of the focal species. Double-counting was avoided by mapping flocks, noting flock traits such as size and sex and age composition. Observations were checked by both teams just after the survey.

Transects were driven during the three hours after sunrise, avoiding the middle part of the day when bustards are less active and less detectable (Martínez 2000, Alonso et al. 2005). For each observation, we recorded the date, time, exact location on georeferenced 1:10,000 aerial photographs, number of individuals and the habitat used. Habitat availability was measured at 45 points per study sector. Points were selected by extracting random pairs of coordinates and located in the field using aerial photographs and GPS devices. The number of randomly selected 
points was established considering both logistic constraints and expected maximum number of flocks to be located to avoid largely unbalanced designs. Distances covered were computed on aerial photographs after field checking using Autocad 2000. Habitat use and availability were measured as the proportion of habitat types (Appendix 1 ) in a circle of $100 \mathrm{~m}$ radius around each flock located and around random points, respectively, as well as the distance of flocks and points from the nearest road, track and building. Circles around random points and flocks did not overlap in any case.

\section{Statistical analyses}

Seasonal differences in habitat availability between sectors were analysed by means of MANOVA with two fixed factors (study sector and month), using as dependent variables the arcsine transformed proportions of each habitat type around random points. Differences between sectors in distances to the nearest road, track and building were analysed by means of a one-way MANOVA on log-transformed data. When analyses were significant, we conducted ANOVAs to detect which habitat or distance variables varied significantly among sectors and/or seasons. The rationale for using MANOVA was that cover of each habitat-type must be intercorrelated because of the unit sum constraint (i.e. the sum of all the cover is necessarily one, as the set of variables is mutually exclusive and exhaustive; Aebischer et al. 1993), whereas distance variables are likely to be intercorrelated because they are influenced by the same process, i.e. development. We did not perform a single MANOVA because a) habitat variables varied seasonally whereas distance variables did not and $b$ ) there were no a priori reasons to expect intercorrelations between habitat-type and development variables.

Habitat selection was analysed using three-way MANOVAs with the following fixed factors: sector, season (autumn: September-December; winter: January-March; spring: April-June), and whether data correspond to a Great Bustard flock (habitat use) or to a random point (habitat availability). Dependent variables were either the proportion of habitat types in $100 \mathrm{~m}$ circles or distances to the nearest road, track and building, after data transformation. Significant effects of the use/availability factor will show habitat selection, whereas significant interactions between the effect of the use/availability factor and the effects of either sector or season will indicate seasonal or between-sector differences in habitat selection by Great Bustards. One- or two-way ANOVAs were carried out when MANOVAs detected significant interactive effects in order to establish which habitat or distance variables were responsible for the detected multivariate effect. We used Great Bustard flocks rather than individuals as sample units because birds in flocks cannot be considered independent observations, and we pooled data seasonally due to small samples sizes for some months and/or sectors. We used GLM (ANOVA) tests rather than GLZs based on the binomial distribution (logistic or binomial regressions) because a) the latter are much more sensitive to unbalanced designs and b) intrinsically low sample sizes associated with scarce and endangered species would have precluded testing the pure and interactive effects of large sets of land-use variables (McCullagh and Nelder 1997).

As flocking could influence habitat selection behaviour, we tested for differences in group size among sites and months using GLZs with Poisson distribution and log-link, corrected for overdispersion. We used total monthly population size as a covariate to remove its effects on flock size. All analyses were performed with STATISTICA 6.o (StatSoft 2002).

\section{Results}

\section{Habitat availability}

The availability of habitat types varied both between sectors and monthly (Wilks' $\lambda=0.716$; $\mathrm{df}=$ 8,$785 ; P<0.001$ and $\lambda=0.564 ; \mathrm{df}=64,4,534 ; P<0.001$, respectively). Monthly variation also differed between sectors $(\lambda=0.896 ; \mathrm{df}=64,4,534 ; P=0.029)$. Growing cereals, ploughed 
fields and stubble were the dominant habitat types in Miguelturra, whereas the area of fallow (both short- and long-term) and grasslands was larger in Ballesteros (Figure 2). Monthly variation was due to increasing proportions of fields with growing cereals and decreasing proportions of stubble and ploughed fields from October to February due to sowing, and to the shift from cereals to stubble after harvesting in May-June $\left(\mathrm{F}_{8,792}=4.2-36.9, P<0.001\right.$ for cereal, ploughed field and stubble areas, $\mathrm{F}_{8,792}<2.7, P>0.05$ for the rest of habitat types; effect of month in two-way ANOVAs with sector and month as fixed factors; monthly data not shown). Between-sector differences in monthly variation could be attributed to the weaker effects of changes associated with sowing and harvesting in Ballesteros $\left(\mathrm{F}_{8,792}=4.3-4.4, P<\right.$ 0.001 for cereal and stubble areas, $\mathrm{F}_{8,792}<2.6, P>0.05$ for the rest of habitat types; month $\mathrm{x}$ sector interaction in two-way ANOVAs with sector and month as fixed factors; monthly data not shown), where permanent habitat types (fallow and grassland) were more abundant (Figure 2). Distances of random points to tracks, roads and buildings did not differ between sectors $(\lambda=$ 0.944; $\mathrm{df}=3,87 ; P=0.172$ ).

\section{Habitat selection}

We located 71 flocks including 815 individuals between September 2002 and June 2003 (Appendix 2). Numbers of flocks and birds peaked in winter and were lower in Ballesteros than in Miguelturra throughout the year (López-Jamar et al. 2004). Habitat use by Great Bustards differed significantly from availability throughout the study period $(\lambda=0.963 ; \mathrm{df}=8,894 ; \mathrm{P}<$ 0.001). Ploughed fields were negatively selected $(5.93 \pm 0.17 \%$ vs. $15.93 \pm 0.03 \%$; mean \pm SE cover around used $v$ s random points, back transformed) whereas both short- and long-term fallow were selected positively (Table 1 ). Habitat selection patterns changed seasonally $(\lambda=0.961$; $\mathrm{df}=16,1,788 ; P=0.003)$, as positive selection of short-term fallow was stronger in winter and spring whereas selection of long-term fallow was stronger in autumn (Figure 3; Table 1). Finally,

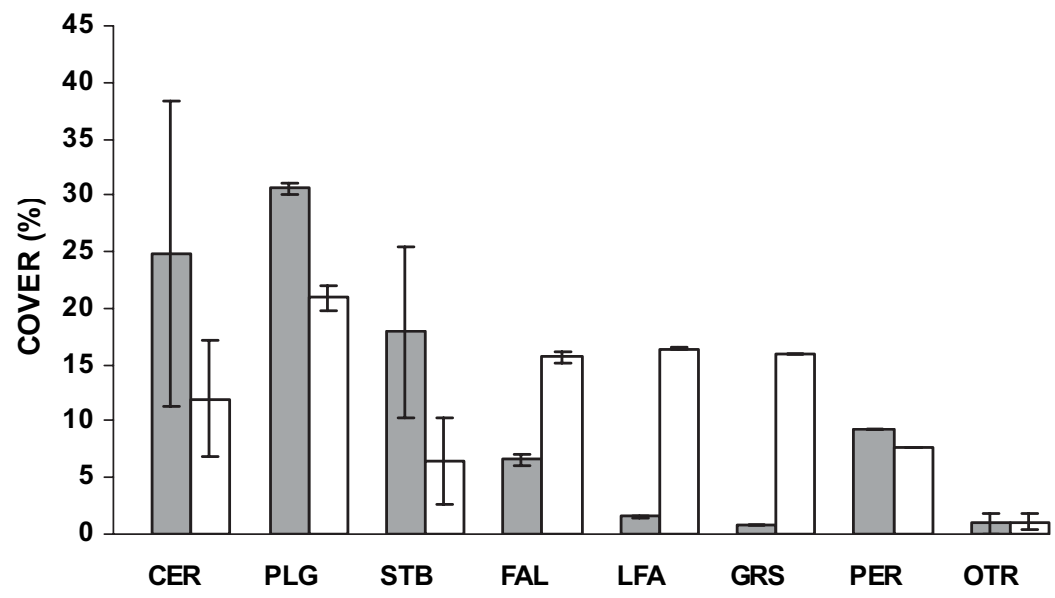

Figure 2. Mean monthly availability $\pm \mathrm{SD}(n=9$; back-transformed $)$ of habitat types during the study period in the two study sectors (grey bars: Miguelturra; open bars: Ballesteros). CER: growing cereals; PLG: ploughed fields; STB: stubble; FAL: short-term fallow; LFAL: long-term fallow; GRS: grassland; PER: perennial crops (olive groves and vineyards); OTR: others (see Appendix 1 for details). Between-sector differences were significant for all habitat types $\left(\mathrm{F}_{1,792}=\right.$ 15.1-67.7, $P<0.001$; effect of sector in two-way ANOVAs with sector and month as fixed factors) but for perennial crops and others $\left(\mathrm{F}_{1,792}=0.0,4.2, P>0.05\right)$. 

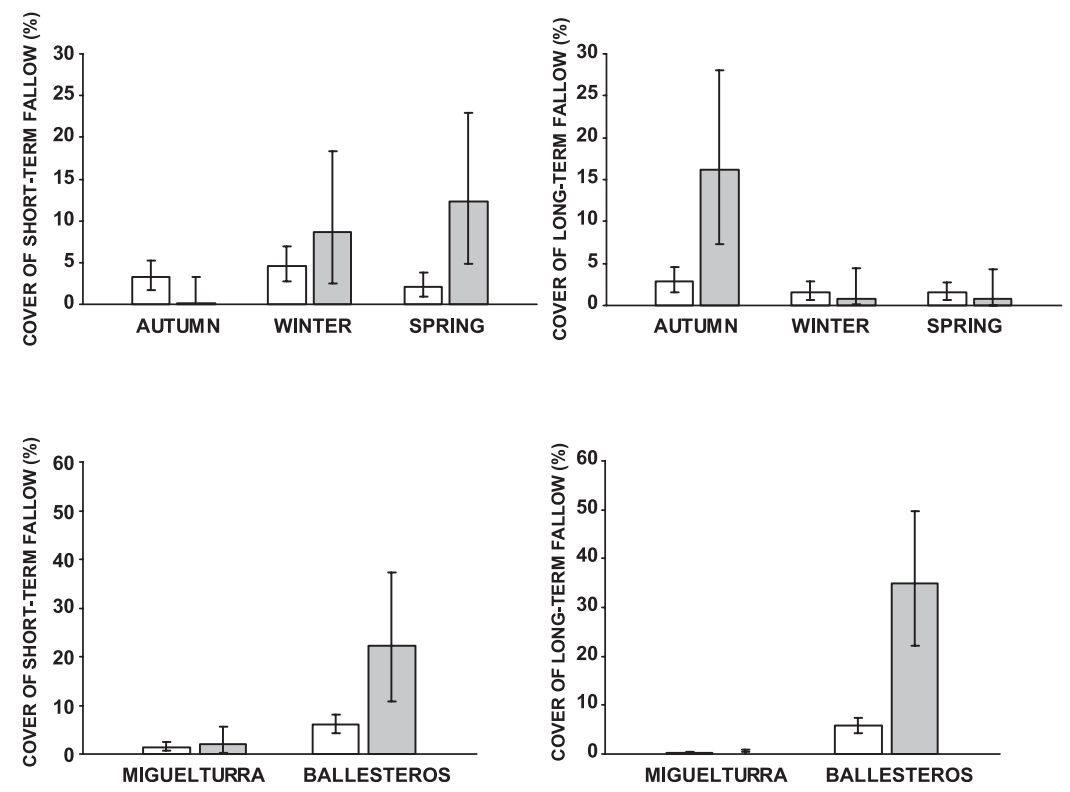

Figure 3. Seasonal (upper) and between-sector (lower) differences between use (grey) and availability (white) of short- and long-term fallow. Bars indicate mean cover of fallow in 100-m circles around random points (availability) or around points occupied by Great Bustard flocks (use), and whiskers 95\% confidence intervals (back-transformed).

patterns of habitat selection differed between sectors $(\lambda=0.960 ; \mathrm{df}=8,894 ; P<0.001)$. In fact, short- and long-term fallow were selected positively in the Ballesteros sector only, whereas in Miguelturra use and availability did not differ significantly (Figure 3; Table 1). No significant three-way interaction between use/availability, study sector and season was found $(\lambda=0.973$; $\mathrm{df}=16,1,788 ; P=0.078)$. Use of habitats other than ploughed fields or fallows did not differ from availability in any study sector of season (Table 1 ).

Great Bustard flocks were found farther away from roads, tracks and buildings than available $(\lambda=0.955 ; \mathrm{df}=3,899 ; P<0.001 ;$ Table 1 , Figure 4$)$, and this avoidance of structures did not change significantly throughout the study period $(\lambda=0.998 ; \mathrm{df}=6,1,798 ; P=0.935 ;$ Table 1$)$. However, avoidance of tracks and buildings differed significantly among study sectors $(\lambda=$ 0.987; df $=3$, 899; $P=0.007$; Table 1). Great Bustard flocks were located much farther away from tracks and buildings in Ballesteros than in Miguelturra (Figure 4). No significant three-way interaction between use/availability, study sector and season was found $(\lambda=0.996$; $\mathrm{df}=6$, 1,798; $P=0.708$ ).

Flock size changed monthly, peaking during fall-winter $\left(\chi_{8}^{2}=74.71, P<0.0001\right)$, but did not differ between study sectors $\left(\chi_{1}^{2}=3.80, P=0.051\right)$. The study sector $\mathrm{x}$ month interaction was not significant either $\left(\chi_{6}^{2}=4.32, P=0.634\right)$. Marginal differences in flock size between study sectors were due to overall differences in population size (see also López-Jamar et al. 2004), as the study sector effect becomes non-significant $\left(\chi_{1}^{2}=2.45, P=0.118\right)$ when monthly number of individuals was introduced as a covariate $\left(\chi_{1}^{2}=49.78, P<\right.$ o.ooo1 $)$. Monthly effects remained significant $\left(\chi_{8}^{2}=24.33, P=0.002\right)$ and the study sector $\mathrm{x}$ month interaction not significant $\left(\chi_{5}^{2}=3.04\right.$, $P=0.694)$. Lack of significant differences in flocking behaviour between study sectors suggested that differences in patterns of aggregation by birds between sectors would not have biased results on habitat selection patterns. 
Table 1. Results of the three-way ANOVAs testing for the interactive effects of study sector and season on the differences in the cover of each habitat type and in the distance to infrastructure between points where Great Bustard flocks were located (use; U) and random points (availability; A). Significant effects of the use/ availability factor indicate that habitat use differed from random expectations (i.e. habitat selection), whereas interactive effects of study area and/or season indicate significant spatial or temporal changes in habitat selection. No overall three-way interactions were significant (MANOVAs with either cover of habitat types or distances as dependent variables; see text). Areas of cover were arcsine-transformed and distances logtransformed. See text for details. Habitat types: CER: growing cereals; PLG: ploughed fields; STB: stubble; FAL: short-term fallow; LFAL: long-term fallow; GRS: grassland; PER: perennial crops (olive groves and vineyards); OTR: others.

\begin{tabular}{|c|c|c|c|c|c|c|c|c|c|c|c|c|}
\hline & & CER & PLG & STB & FAL & LFAL & GRS & PER & OTR & ROAD & TRACK & BUILD. \\
\hline & $\mathrm{df}$ & $\mathrm{F}(P)$ & $\mathrm{F}(P)$ & $\mathrm{F}(P)$ & $\mathrm{F}(P)$ & $\mathrm{F}(P)$ & $\mathrm{F}(P)$ & $\mathrm{F}(P)$ & $\mathrm{F}(P)$ & $\mathrm{F}(P)$ & $\mathrm{F}(P)$ & $\mathrm{F}(P)$ \\
\hline $\mathrm{U} / \mathrm{A}$ & 1,901 & $\begin{array}{l}\text { o.06 } \\
\text { (n.s.) }\end{array}$ & $\begin{array}{l}9.70 \\
(<0.01)\end{array}$ & $\begin{array}{l}\text { 0.19 } \\
\text { (n.s.) }\end{array}$ & $\begin{array}{l}8.62 \\
(<0.01)\end{array}$ & $\begin{array}{l}15.75 \\
(<0.001)\end{array}$ & $\begin{array}{l}\text { 1.32 } \\
\text { (n.s.) }\end{array}$ & $\begin{array}{l}1.63 \\
\text { (n.s.) }\end{array}$ & $\begin{array}{l}\text { o.8o } \\
\text { (n.s.) }\end{array}$ & $\begin{array}{l}11.15 \\
(<0.001)\end{array}$ & $\begin{array}{l}14.47 \\
(<0.001)\end{array}$ & $\begin{array}{l}34.44 \\
(<0.001)\end{array}$ \\
\hline $\begin{array}{l}\text { U/A x } \\
\text { Season }\end{array}$ & 2,901 & $\begin{array}{l}\text { o.62 } \\
\text { (n.s.) }\end{array}$ & $\begin{array}{l}\text { O.13 } \\
\text { (n.s.) }\end{array}$ & $\begin{array}{l}1.71 \\
\text { (n.s.) }\end{array}$ & $\begin{array}{l}8.78 \\
(<0.001)\end{array}$ & $\begin{array}{l}7.29 \\
(<0.001)\end{array}$ & $\begin{array}{l}\text { 1.88 } \\
\text { (n.s.) }\end{array}$ & $\begin{array}{l}\text { o.66 } \\
\text { (n.s.) }\end{array}$ & $\begin{array}{l}\text { o.16 } \\
\text { (n.s.) }\end{array}$ & $\begin{array}{c}\text { o.68 } \\
\text { (n.s.) }\end{array}$ & $\begin{array}{r}\text { o.17 } \\
\text { (n.s.) }\end{array}$ & $\begin{array}{r}0.09 \\
\text { (n.s.) }\end{array}$ \\
\hline $\begin{array}{l}\text { U/A x } \\
\text { Sector }\end{array}$ & 1,901 & $\begin{array}{l}2.98 \\
\text { (n.s.) }\end{array}$ & $\begin{array}{l}\text { O.03 } \\
\text { (n.s.) }\end{array}$ & $\begin{array}{l}2.96 \\
\text { (n.s.) }\end{array}$ & $\begin{array}{l}6.99 \\
(<0.01)\end{array}$ & $\begin{array}{l}21.56 \\
(<0.001)\end{array}$ & $\begin{array}{l}2.09 \\
\text { (n.s.) }\end{array}$ & $\begin{array}{l}\text { 1.06 } \\
\text { (n.s.) }\end{array}$ & $\begin{array}{l}0.38 \\
\text { (n.s.) }\end{array}$ & $\begin{array}{c}0.69 \\
\text { (n.s.) }\end{array}$ & $\begin{array}{c}7.10 \\
(<0.01)\end{array}$ & $\begin{array}{c}4.83 \\
(<0.05)\end{array}$ \\
\hline
\end{tabular}

\section{Discussion}

Habitat selection by Great Bustards in Campo de Calatrava did not differ qualitatively from patterns reported already (Alonso and Alonso 1990, Hidalgo and Carranza 1990, Palacín et al. 1996, Lane et al. 2001, Suárez-Seoane et al. 2002, Morales et al. 2006). Avoidance of ploughed fields and positive selection of fallows (both short- and long-term) are usually related to the amount of food resources provided (Hidalgo and Carranza 1990, Lane et al. 1999), which is lowest in ploughed fields and highest in fallows (Díaz and Tellería 1994). Great Bustard distribution was also influenced by human infrastructures such as buildings, roads and tracks, which the bird avoids consistently throughout its distribution range (Alonso and Alonso 1990, Hidalgo and Carranza 1990, Lane et al. 2001).

We found significant differences in the strength of habitat selection patterns of Great Bustards between the two nearby study sectors. Overall, birds positively selected fallows in the sector sited close to a development project, the Ciudad Real airport, whereas in a study sector $5 \mathrm{~km}$ away, they used fallows according to their availability (Figure 1). Great Bustards selected the best habitat types (short- and long-term fallows; Hidalgo and Carranza 1990, Lane et al. 1999) in the area subject to recent changes, while no significant selection of these habitats was found in the area with predominantly agricultural use. This result may arise from the dependence of habitat

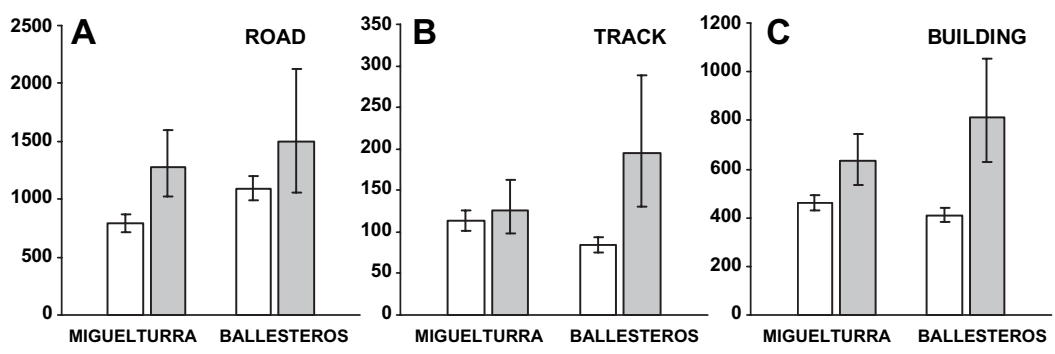

Figure 4. Mean distances $\pm 95 \%$ confidence intervals (back-transformed) of random points (white bars) and Great Bustard flocks (grey bars) to the nearest road, track and building according to study sector. 
selection patterns on population density (Fretwell and Lucas 1970), as selection of optimal habitats is expected to be strongest when population density is constrained by resourceindependent factors such as, in our case, the avoidance of man-made structures. In fact, bustard flocks located close to the development project were found significantly farther away from manmade structures (tracks and buildings) than flocks located in the control sector, in spite of nonsignificant differences in the density of these structures between sectors. The most parsimonious explanation for this result seems to be that tracks and buildings were used by man more frequently in the developed sector, and bustards responded to higher levels of human use by avoiding infrastructure more strongly (Alonso and Alonso 1990, Lane et al. 2001, Suárez-Seoane et al. 2002, Sastre et al. 2009), as found in other studies relating levels of human disturbance to bird density and habitat use (e.g. Reijnen et al. 1996, Bautista et al. 2004, reviewed in Fahrig and Rytwinski 2009). Although we did not gather specific data on levels of human disturbance between study sectors, the start of development work in the airport area during the study period produced an obvious increase in human presence in and around the developed sector.

Increased human use of structures in the developed area would have then led to a reduction in the area suitable for bustards, a decrease in population size, and a change in the patterns of resource-based habitat selection. In fact, the local population of Great Bustards seems to have increased slightly in the last few years, but apparently due to a process of concentration of birds into less disturbed areas rather than to a general increase in population growth (López-Jamar et al. 2004, Gosálvez 2007, authors' unpubl. data). The opposite process, i.e. that abandonment of agricultural use in the developed area could have been the cause of both lower population density and stronger avoidance of buildings, tracks and roads should imply that the remaining highsuitability habitats (short- and long-term fallows) would have been located farther away from these infrastructures. However, the proportion of fallows at random points was not correlated with distance to infrastructure $\left(r^{2}=0.04, P=0.289\right.$ and $r^{2}=0.02, P=0.573$; multiple regression for distances as predictors and cover of short- and long-term fallows, respectively), and such lack of correlation did not differ among study areas (ANCOVAs; $F_{2,82}=0.03-2.10, P=$ 0.966-0.129 for the interactions study area $\mathrm{x}$ distances on proportion of fallows).

Currently, most management efforts directed at the conservation of Great Bustards and other steppe birds are focused on the development and application of agri-environment schemes aimed at reversing the negative effects of agricultural intensification (review in Bota et al. 2005). The design of these schemes, and the evaluation of their effectiveness, still relies heavily on knowledge of the average habitat requirements of the species involved or communities throughout their distribution range (e.g. Llusía and Oñate 2005). Our results indicate that habitat selection patterns by Great Bustards changed locally in relation to a process (infrastructure development) which is not addressed by agricultural schemes. In fact, landscapescale effects of agricultural intensification seem to constrain their effectiveness, as such schemes are forced to act mainly at field scales (Concepción et al. 2008). Our study indicates how landscape-scale effects of land use other than agriculture may also constraint the effectiveness of schemes by modifying the habitat selection patterns of farmland birds locally, besides the regional changes already documented by other authors (Whittingham et al. 2007).

Habitat preferences of Great Bustard vary throughout the year, with the species favouring shortand long-term fallows at different seasons. This underlines the need to maintain these habitats within the agricultural mosaic, as widely acknowledged. Permanent abandonment of agricultural activity will decrease habitat suitability for bustards, as has been found for other open country birds (Nikolov 2010). These effects will be amplified if agriculture is replaced by infrastructure (tracks, roads and buildings) linked to development projects. Vehicle traffic has been described as the main source of disturbance to Great Bustards (Sastre et al. 2009) and the opening of new tracks or any increase in their use might affect bird behaviour and distribution (Bautista et al. 2004, Sastre et al. 2009) making current conservation efforts to preserve bustard populations ineffective. Therefore, the development and application of measures aimed at preserving the suitability of agricultural habitats to bustards (i.e. agri-environmental schemes) should also include landscape-scale 
restrictions to the development and use of infrastructure. Otherwise, efforts to preserve suitable agricultural areas would not be effective in preserving their farmland birds.

\section{Acknowledgements}

SEO/BirdLife supported field work through a grant programme for local groups. We are very grateful to people who aided with field work, especially to Ángel V. Arredondo, Rafael U. Gosálvez, Montse Morales, Luis Carlos Ramos, Darío Rodríguez-Madridejos and Luis A. Segura. Roberto Carbonell, Elena D. Concepción, Pedro P. Olea, David Serrano, Susana Suárez-Seoane and an anonymous referee made useful comments on previous drafts. Fabian Casas was supported by a post-doctoral grant from the Junta de Comunidades de Castilla La Mancha (JCCM) while writing this paper. This work is a contribution to the project EASY (Evaluating current European Agri-environment Schemes to quantify and improve nature conservation efforts in agricultural landscapes), financed by the V Framework Program of the EU (www.dow.wau.nl/natcons/NP/ EASY) and to the project AGRIPOPES of the European Science Foundation.

\section{References}

Aebischer, N. J., Robertson, P. A. and Kenward, R. E. (1993) Compositional analysis of habitat use from animal radio-tracking data. Ecology 74: 1313-1325.

Alonso, J. C. and Alonso, J. A. (1990) Parámetros demográficos, selección de hábitat y distribución de la Avutarda (Otis tarda) en tres regiones españolas. Madrid: ICONA.

Alonso, J. C., Martín, C. A., Alonso, J. A., Palacín, C., Magaña, M. and Lane, S. J. (2004) Distribution dynamics of a great bustard metapopulation throughout a decade: influence of conspecific attraction and recruitment. Biodivers. Conserv. 13: 1659-1674.

Alonso, J. C., Palacín, C. and Martín, C. A. (2005) La Avutarda Común en la península Ibérica: población actual y método de censo. Madrid: SEO/BirdLife.

Atkinson, P. W. and Robinson, R. A. (2002) Landscape diversity and bird populations: the need for regionally flexible and scaledependent agri-environment schemes. Pp. 289-299 in D. Chamberlain and A. Wilson, eds. Avian landscape ecology. Pure and applied issues in the large-scale ecology of birds. Proceedings of the 2002 Annual IALE Conference. International Association for Landscape Ecology.

Bautista, L. M., García, J. T., Calmaestra, R. G., Palacín, C., Martín, C. A., Morales, M. B., Bonal, R. and Viñuela, J. (2004) Effect of weekend road traffic on the use of space by raptors. Conserv. Biol. 18: 1-7.
Benton, T. G., Vickery, J. A. and Wilson, J. D. (2003) Farmland biodiversity: is habitat heterogeneity the key? Trends Ecol. Evol. 18: 182-188.

BOE (2001) Environmental impact declaration of the Ciudad Real airport project. 109: 1630-16375. (In Spanish).

BOE (2002) Environmental impact declaration of the project 'modification of the Plan of the Ciudad Real Airport as proposed by the European Union. 302: 44562-44569. (In Spanish).

BOE (2006) Environmental impact declaration of the 'Aeropuerto Don Quijote' (Ciudad Real) airport project. 46: 7591-7603. (In Spanish).

BOE (2008) Resolution of not submitting the modification of the Ciudad Real airport project to the process of Environmental Impact Assessment. 302: 50542-50544. (In Spanish).

BOE (2009) Authorization for the operational start of the Ciudad Real airport. 19: 74817486. (In Spanish).

Bota, G., Morales, M. B., Mañosa, S. and Camprodon, J. (2005) Ecology and conservation of steppe-land birds. Barcelona, Spain: Lynx Edicions \& Centre Tecnològic Forestal de Catalunya.

Brotons, L., Mañosa, S. and Estrada, J. (2004) Modelling the effects of irrigation schemes on the distribution of steppe birds in Mediterranean farmland. Biodivers. Conserv. 13: 1039-1058. 
Casas, F., Mougeot, F., Viñuela, J. and Bretagnolle, V. (2009) Effects of hunting on the behaviour and spatial distribution of farmland birds: importance of hunting-free refuges in agricultural areas. Anim. Conserv. 12: 346-354.

Chamberlain, D. E., Fuller, R. J., Bunce, R. G. H., Duckworth, J. C. and Shrubb, M. (200o) Changes in the abundance of farmland birds in relation to the timing of agricultural intensification in England and Wales. J. Appl. Ecol. 37: 771-788.

Concepción, E. D., Díaz, M. and Baquero, R. A. (2008) Effects of landscape complexity on the ecological effectiveness of agrienvironment schemes. Landscape Ecol. 23: 135-148.

Díaz, M. and Tellería, J. L. (1994) Predicting the effects of agricultural changes in central Spain croplands on seed-eating overwintering birds. Agr. Ecosyst. Environ. 49: 289-298.

Díaz, M., Illera, J. C. and Hedo, D. (2001) Strategic environmental assessment of plans and programs: a methodology for biodiversity evaluations. Environ. Manage. 28: 267-279.

Donald, P. F., Green, R. E. and Heath, M. F. (2001) Agricultural intensification and the collapse of Europés farmland bird populations. Proc. R. Soc. Lond. B 268: 25-29.

Donald, P. F., Sanderson, F. J., Burfield, I. J., Bierman, S. M., Gregory, R. D. and Waliczky, Z. (2007) International conservation policy delivers benefits for birds in Europe. Science 317: 810-813.

Fahrig, L. and Rytwinski, T. (2009) Effects of roads on animal abundance: an empirical review and synthesis. Ecol. Soc. 14: 21. [online] URL: http://www.ecologyandsociety.org/voli4/issi/art21/

Fretwell, S. D. and Lucas, H. L. (1970) On territorial behaviour and other factors influencing habitat distribution in birds. I. Theoretical development. Acta Biotheorica 19: $16-36$.

Fox, A. D. and Madsen, J. (1997) Behavioural and distributional effects of hunting disturbance on waterbirds in Europe: implications for refuge design. J. Appl. Ecol. 34: 1-13.

Gill, J. A., Norris, K. and Sutherland, W. J. (2001) Why behavioural responses may not reflect the population consequences of human disturbance. Biol. Conserv. 97: 265268.

Gosálvez, R. U. (2007) Distribución y tamaño poblacional de la avutarda común Otis tarda en la ZEPA Área esteparia del Campo de Calatrava (invierno, 2004-primavera, 2005). Pp. 191-196 in F. Casas, A. V. Arredondo and J. López-Jamar, eds. Anuario ornitológico de Ciudad Real 2004-2005. Ciudad Real: SEO-Ciudad Real.

Hidalgo, S. J. and Carranza, J. (1990) Ecología y comportamiento de la Avutarda (Otis tarda L.). Cáceres: Servicio de Publicaciones de la Universidad de Extremadura.

Lane, S. J., Alonso, J. C., Alonso, J. A. and Naveso, M. A. (1999) Seasonal changes in diet selection of great bustards Otis t. tarda in north-west Spain. J. Zool. 247: 201-214.

Lane, S. J., Alonso, J. C. and Martín, C. A. (2001) Habitat preferences of great bustard Otis tarda flocks in the arable steppes of central Spain: are potentially suitable areas unoccupied? J. Appl. Ecol. 38: 193-203.

Llusía, D. and Oñate, J. J. (2005) Are the conservation requirements of pseudosteppe birds adequately covered by Spanish agri-environmental schemes? An ex-ante assessment. Ardeola 52: 31-42.

López-Jamar, J., Casas, F. and Díaz, M. (2004) Dinamica estacional de la población de Avutarda común Otis tarda en el Campo de Calatrava. Pp. 101-107 in C. Torralvo, ed. Anuario ornitológico de Ciudad Real 2002-2003. Ciudad Real: SEO-Ciudad Real.

Martínez, C. (2000) Daily activity patterns of Great Bustard Otis tarda. Ardeola 47: 57-68.

McCullagh, P. and Nelder, J. A. (1997) Generalized linear models, 2nd edition. Boca Raton, Florida: Chapman \& Hall/CRC.

Morales, M. B. and Martín, C. A. (2002) Great Bustard Otis tarda. BWP Update 4: 217-232.

Morales, M. B., Suárez, F. and de la Morena, E. L. G. (2006) Response of steppe birds to various levels of farming intensity and of modification of the agricultural landscape: a comparative analysis of their effects on population density and habitat selection in the Little and Great Bustards (Tetrax tetrax 
and Otis tarda). Revue D'Ecologie-La Terre et la Vie 61: 261-270.

Morrison, M. L., Marcot, B. G. and Mannan, R. W. (1998) Wildlife-habitat relationships. Concepts and applications. 2nd edition. Madison, Wisconsin: University of Wisconsin Press.

Nikolov, S. C. (2010) Effects of land abandonment and changing habitat structure on avian assemblages in upland pastures of Bulgaria. Bird Conserv. Int. 20: 200-213.

Onrubia, A. and Andrés, T. (2005) Impact of human activities on steppic-land birds: a review in the context of the Western Palearctic. Pp. 185-209 in G. Bota, M. B. Morales, S. Mañosa and J. Camprodon, eds. Ecology and conservation of steppeland birds. Barcelona: Lynx Edicions \& Centre Tecnològic Forestal de Catalunya.

Osborne, P. (2005) Using GIS, remote sensing and modern statistics to study steppe birds at large spatial scales: a short review essay. Pp. $169-184$ in G. Bota, M. B. Morales, S. Mañosa and J. Camprodon, eds. Ecology and conservation of steppe-land birds. Barcelona: Lynx Edicions \& Centre Tecnològic Forestal de Catalunya.

Palacín, C. and Alonso, J. C. (2008) An updated estimate of the world status and population trends of the great bustard Otis tarda. Ardeola 55: 13-25.

Palacín, C., Campos, B. and Pinilla, J. (1996) Demografía y uso del hábitat de la avutarda (Otis tarda) en Castilla-La Mancha. Pp. 183-190 in J. Fernández and J. Sanz-Zuasti, eds. Conservación de las aves esteparias y su hábitat. Valladolid: Junta de Castilla y León.

Palacín, C., Alonso, J. C., Martín, C. A., Alonso, J. A., Magaña, M. and Martín, B. (2003) Avutarda Común, Otis tarda. Pp. 236-237 in R. Martí, and J. C. Del Moral, eds. Atlas de las aves reproductoras de España. Madrid: Dirección General de Conservación de la Naturaleza-Sociedad Española de Ornitología.

Palacín, C., Alonso, J. C., Martín, C. A., Alonso, J. A., Magaña, M. and Martín, B. (2004). Avutarda Común Otis tarda. Pp. 209-213 in A. Madroño, C. González and J. C. Atienza, eds. Libro Rojo de las aves de España. Madrid: Dirección General de la
Conservación de la Naturaleza-Sociedad Española de Ornitología.

Reijnen, R., Foppen, R. and Meeuwsen, H. (1996) The effects of traffic on the density of breeding birds in Dutch agricultural grasslands. Biol. Conserv. 75: 255-260.

Sastre, P., Ponce, C., Palacín, C., Martín, C. A. and Alonso, J. C. (2009) Disturbances to great bustards (Otis tarda) in central Spain: human activities, bird responses and management implications. Eur. J. Wildl. Res. 55: 425-432.

Schlaepfer, M. A., Runge, M. C. and Sherman, P. W. (2002) Ecological and evolutionary traps. Trends Ecol. Evol. 17: 474480 .

StatSoft, Inc. (2002) STATISTICA data analysis software system, version 6. www. statsoft.com.

Suárez, F., Herranz, J., de la Morena, E. L. G., Morales, M. B. and Malo, J. E. (200o) Estudio ornitológico del emplazamiento seleccionado para el aeropuerto de Ciudad Real y diagnóstico de su posible afección sobre las poblaciones de aves. Aeropuerto de Ciudad Real/Departamento Interuniversitario de Ecología (Universidad Autónoma de Madrid). Madrid. [Unpublished report]

Suárez-Seoane, S., Osborne, P. E. and Alonso, J. C. (2002) Large-scale habitat selection by agricultural steppe birds in Spain: identifying species-habitat responses using generalized additive models. J. Appl. Ecol. 39: 755-771.

Tellería, J. L., Santos, T. and Díaz, M. (1994) Effects of agricultural practices on bird populations in the Mediterranean region: the case of Spain. Pp. 57-75 in E. J. M. Hagemeijer and T. J. Verstrael, eds. Bird numbers 1992. Distribution, monitoring and ecological aspects. Beek-Ubbergen, The Netherlands: Statistics Netherlands \& SOVON.

Traba, J., de la Morena, E. L. G., Morales, M. B. and Suárez, F. (2007) Determining high value areas for steppe birds in Spain: hot spots, complementarity and the efficiency of protected areas. Biodivers. Conserv. 16: 3255-3275.

Webb, N. V. and Blumstein, D. T. (2005) Variation in human disturbance differentially 
affects predation risk assessment in Western Gulls. Condor 107: 178-181.

Whittingham, M. J., Krebs, J. R., Swetnam, R. D., Vickery, J. A., Wilson, J. D. and Freckleton,
R. P. (2007) Should conservation strategies consider spatial generality? Farmland birds show regional not national patterns of habitat association. Ecol. Letters 10: 25-35.

\section{JUAN LÓPEZ-JAMAR}

Universidad de Castilla La Mancha, Fac. Ciencias Medio Ambiente, Dept. Ciencias Ambientales, 45071 Toledo, Spain.

Current address: C/ País Valenciano 5, $2^{\circ}$ H., 13004 Ciudad Real, Spain.

\section{FABIÁN CASAS*}

Instituto de Investigación en Recursos Cinegéticos, IREC (CSIC, UCLM, JCCM), Ronda de Toledo s/n., 13071 Ciudad Real, Spain.

\section{MARIO DÍAZ}

Instituto de Recursos Naturales (IRN-CCMA-CSIC), c/Serrano 115 bis, 28006 Madrid, Spain.

\section{MANUEL B. MORALES}

Grupo de Ecología Terrestre (TEG) Dpto. de Ecología, Facultad de Ciencias, Universidad Autónoma de Madrid, 28049 Madrid, Spain.

*Author for correspondence; e-mail: Fabian.Casas@uclm.es

Received 25 February 2010; revision accepted 8 July 2010;

Published online 3 November 2010 


\section{Appendices}

Appendix 1. Habitat types available in the Campo de Calatrava during the study period. Selection and definition of habitat types follow Morales et al. (2006) and references therein.

\begin{tabular}{|c|c|}
\hline Habitat type & Description \\
\hline Growing cereal & Growing fields of dry cereals (barley, wheat or oats) \\
\hline Ploughed fields & $\begin{array}{l}\text { Fields ploughed recently and not yet sown, so that vegetation cover was almost } \\
\text { absent }(<20 \%)\end{array}$ \\
\hline Stubble & Recently-harvested cereal or legume fields, still covered with harvest remains \\
\hline Short-term fallow & $\begin{array}{l}\text { Fields left unsown during the year following harvest, so that natural vegetation } \\
\text { usually covered more than } 20 \% \text { of the ground }\end{array}$ \\
\hline Long-term fallow & Fields left unsown for more than one year after harvest and used as pasture \\
\hline Grassland & Permanent grassland and low scrub \\
\hline Perennial crops & Olive groves and vineyards \\
\hline Others & $\begin{array}{l}\text { Annual crops of legumes (Vicia spp. or Pisum sativum) or Sugar Beet Beta } \\
\text { rubra, usually irrigated }\end{array}$ \\
\hline
\end{tabular}

Appendix 2. Monthly numbers of Great Bustard flocks and individuals contacted in the two study sectors and median flock size (see also López-Jamar et al. 2004).

\begin{tabular}{|c|c|c|c|c|c|c|}
\hline & \multicolumn{3}{|c|}{ MIGUELTURRA } & \multicolumn{3}{|c|}{ BALLESTEROS } \\
\hline & $\begin{array}{l}\text { No. } \\
\text { flocks }\end{array}$ & $\begin{array}{l}\text { No. } \\
\text { individuals }\end{array}$ & $\begin{array}{l}\text { Flock size } \\
\text { (median/range) }\end{array}$ & $\begin{array}{l}\text { No. } \\
\text { flocks }\end{array}$ & $\begin{array}{l}\text { No. } \\
\text { individuals }\end{array}$ & $\begin{array}{l}\text { Flock size } \\
\text { (median/range) }\end{array}$ \\
\hline September & 4 & 58 & $6(2-44)$ & $\mathrm{o}$ & $\mathrm{o}$ & $\mathrm{o}(\mathrm{O}-\mathrm{O})$ \\
\hline October & 6 & 90 & $24(5-37)$ & 1 & 16 & $16(16-16)$ \\
\hline December & 9 & 114 & $10(2-32)$ & 10 & 74 & $5 \cdot 5(1-22)$ \\
\hline January & 8 & 131 & $12.5(2-51)$ & 3 & 57 & $25(4-28)$ \\
\hline February & 6 & 89 & $5(1-39)$ & 1 & 16 & $16(16-16)$ \\
\hline March & 7 & 72 & $6(1-20)$ & 4 & 7 & $I(1-4)$ \\
\hline April & 10 & 41 & $3(1-12)$ & 8 & 10 & $I(1-1)$ \\
\hline May & 9 & 15 & $1(1-2)$ & 1 & 2 & $2(2-2)$ \\
\hline June & 4 & 23 & $4(2-8)$ & o & o & $\mathrm{o}(\mathrm{O}-\mathrm{O})$ \\
\hline Total & 63 & 633 & $2(1-51)$ & 28 & 182 & $1(1-28)$ \\
\hline
\end{tabular}

